\title{
Angiomyxoma of the Lower Eyelid with Orbital Extension: A Rare Entity and Review of Literature
}

\author{
Sahil Agrawal', Aarush Deora ${ }^{1}$, Sujeeth Modaboyina ${ }^{1}$, Deepsekhar Das ${ }^{1 *}$, Mandeep Singh Bajaj ${ }^{1}$ and Seema Sen ${ }^{2}$ \\ ${ }^{1}$ Dr. Rajendra Prasad Centre for Ophthalmic Sciences, All India Institute of Medical Sciences New Delhi - 110 029, India \\ ${ }^{2}$ Department of Ocular Pathology, All India Institute of Medical Sciences, New Delhi -110 029, India
}

\begin{abstract}
A 60-year-old male sought medical advice for painless progressive swelling in the left eye associated with protrusion of the eyeball and diminution of vision for the past 6 months. A computed tomography scan was done which revealed a heterogeneous lesion in the inferotemporal orbit lying close to the globe without any bony erosions or intracranial extension. Incisional biopsy revealed spindle or stellate cells in a myxoid matrix with abundant thin-walled vessels. On Immunohistochemistry, the tumour was positive for vimentin and SMA. It was negative for Desmin and S-100. A diagnosis of superficial angiomyxoma of the eyelid with orbital extension was thus made. Surgical excision under general anaesthesia was planned and the mass removed in toto. The histopathological examination of the same revealed findings similar to the incision biopsy. The patient is being followed up with no recurrences till date.
\end{abstract}

Keywords: Angiomyxoma, orbital tumor, proptosis, lid tumor, Carneys complex

\section{Introduction}

In 1983, Steeper and Rosai described a series of distinctive soft tissue tumours of the female pelvis and perineum with the microscopic appearance of a spindle or stellate cells in a loose myxoid stroma with prominent thick-walled vessels with non-arborizing pattern and low mitotic activity. They assigned the term 'aggressive angiomyxoma' ${ }^{[1]}$. Allen et al., in 1988 described 30 uncommon dermal and subcutaneous angiomyxoid tumours in 28 patients. Microscopically, there were moderate to sparsely cellular angiomyxoid nodules with scattered small vessels. They coined the term 'superficial angiomyxoma' for such lesions.

Angiomyxomas are benign mesenchymal tumours. They rarely involve the orbit and a limited number of cases exist in literature. They can be either superficial or deep in nature. Both these varieties have been noted in orbit with one case report documenting malignant rhabdoid transformation ${ }^{[2]}$. They can be locally aggressive, which combined with their gelatinous texture precludes complete surgical removal leading to a high risk of recurrences. These recurrences usually do not cause bony erosions or tissue destruction and therefore can be managed without much morbidity. This study adhered to the tenets of the Declaration of Helsinki, and a written informed consent form was signed by the patient.

\section{Case Report}

A 60-year-old male patient presented to our outpatient department with complaints of swelling in his left lower eyelid and protrusion of the eyeball associated with diminution of vision for the past six months. (Figure 1a) On ophthalmological examination, visual acuity in right eyes was $6 / 6$ on Snellen's visual acuity chart and in the left eye was light perception with an inaccurate projection of rays in temporal and nasal quadrants. Both upper and lower lid fullness was noted on the left side. On Hertel's exophthalmometry, the proptosis of the left eye was found to be $13 \mathrm{~mm}$ with $3 \mathrm{~mm}$ medial dystopia. The swelling was palpable inferiorly from the midpoint of the lower lid, laterally over the lateral canthus and superiorly till beneath the brow. The superior margin could not be felt distinctly. The mass was non-tender, firm in consistency with no palpable pulsations or thrill. It showed resistance to retropulsion with no increase on Valsalva manoeuvre. Bony orbital margins were intact. No lymph nodes were clinically palpable. Extraocular movements were found to be reduced equally in all meridians. On slit-lamp examination, inferior conjunctival prolapse was noted. Pupillary reactions were sluggish, and fundus examination using indirect ophthalmoscopy revealed disc pallor and choroidal folds at the posterior pole. Ophthalmic examination for the right eye revealed no abnormalities. Systemic examination ruled out any other lesions pertaining to Carney's complex. A clinical differential diagnosis of lymphoma, mesenchymal tumors and orbital metastasis was made.

The patient underwent imaging, and on computed tomography, a heterogeneous lesion was noted in the inferotemporal orbit lying in close relation to the globe. (Figure 1c, d). An incisional biopsy was then planned under local infiltrative anaesthesia. 
On histopathological examination of the biopsy, the lesion displayed scattered spindle-to stellate-shaped cells with ill-defined cytoplasm in the loose myxoid stroma with inflammatory cell infiltration. (Figure 2b) The cells had oval, hyperchromatic nuclei with indistinct nucleoli. (Figure 2c) There were no mitotic figures or atypical cells. The stroma was rich in collagen fibres and pale amphophilic to eosinophilic. The tumour was poorly circumscribed with infiltrative margins and displayed abundant thin-walled capillaries and low cellularity. Based on this finding, differentials of superficial anxiomyxoma, myxoid fibrous histiocytoma and dermatofibrosarcoma protuberans.

were made. On further immunohistochemical analysis, the tumour was positive for vimentin and smooth muscle actin and negative for Desmin, indicating myofibroblastic differentiation. (Figure 2d\&e) S-100 staining was also noted to be negative thus ruling out Schwann cell or melanocytic origin. Ki-67 index was less than 1\%, indicating low proliferative activity in the incised mass.

The mass was then removed in toto via lateral orbitotomy under general anaesthesia performed by a modified Burke-Kronlein incision. Grossly the tumour was well- circumscribed myxoid mass measuring 25 x $22 \mathrm{~mm}$. (Figure 2a) The histopathological examination of the removed mass corroborated the findings of the incisional biopsy performed preoperatively.

Following the surgery, the proptosis disappeared. We have a six month follow up of the patient, and there have been no signs of recurrence to date. (Figure 1b)

\section{Discussion}

Anxiomyxomas of the orbit are a rare presentation. A literature search using the MESH terms 'orbital angiomyxoma', 'angiomyxoma', 'orbital tumors' was done on PubMed and goggle scholar, and we found a total of 10 cases of orbital angiomyxomas reported in literature till May 2020. (Table 1)

Though comprising a very rare group of tumours involving the orbit and periorbital cutaneous tissues, angiomyxoma, both superficial and deep/aggressive, need to be considered as differential diagnoses because these tumours are locally aggressive and incomplete removal leads to a high rate of recurrences. These lesions also had a tendency to recur, which ranged from $23 \%$ in tumours without epithelial

Table 1. Review of literature of orbital aniomyxomas.

\begin{tabular}{|c|c|c|c|c|c|c|c|c|}
\hline $\begin{array}{l}\text { Authorl } \\
\text { year }\end{array}$ & Location & $\begin{array}{l}\text { Patient } \\
\text { Any } \\
\text { como- } \\
\text { rbidities }\end{array}$ & $\begin{array}{l}\text { Final } \\
\text { diagnosis }\end{array}$ & Clinical features & Imaging & Treatment & IHC & $\begin{array}{l}\text { Follow up, } \\
\text { recurrence }\end{array}$ \\
\hline $\begin{array}{l}\text { Yuen et } \\
\text { al. } \\
2005^{8}\end{array}$ & $\begin{array}{l}\text { Right upper } \\
\text { lid }\end{array}$ & $47 / \mathrm{M}$ & $\begin{array}{l}\text { Superficial } \\
\text { Angiomyxoma }\end{array}$ & $\begin{array}{l}\text { Palpable painless lid } \\
\text { mass }\end{array}$ & Not Available & $\begin{array}{l}\text { Complete surgical } \\
\text { excision }\end{array}$ & $\begin{array}{l}\text { SMA - } \\
\text { Desmin - } \\
\text { CD34 - } \\
\text { S-100 - }\end{array}$ & NA \\
\hline \multirow[t]{2}{*}{$\begin{array}{l}\text { Hidayat } \\
\text { et al. } \\
2007^{7}\end{array}$} & \begin{tabular}{|l|} 
Case 1 \\
Left orbit, \\
cavernous \\
sinus, base of \\
cranial fossa
\end{tabular} & $7 / \mathrm{M}$ & Angiomyxoma & $\begin{array}{l}\text { Proptosis, loss } \\
\text { of inferior VF, } \\
\text { decreased visual } \\
\text { acuity }\end{array}$ & $\begin{array}{l}\text { MRI showed a tumor } \\
\text { that filled and expanded } \\
\text { the left cavernous } \\
\text { sinus, having extended } \\
\text { from the left orbital } \\
\text { apex, where it involved } \\
\text { the superior and inferior } \\
\text { rectus muscles and } \\
\text { compressed the optic } \\
\text { nerve. }\end{array}$ & $\begin{array}{l}\text { Transcranial orbitotomy } \\
\text { for orbital tumor } \\
\text { excision, dissection } \\
\text { of tumor from cranial } \\
\text { nerves, methotrexate }\end{array}$ & $\begin{array}{l}\text { Vimentin + CD34 + } \\
\text { SMA - } \\
\text { Desmin - }\end{array}$ & $\begin{array}{l}5 \text { months } \\
1 \\
\text { recurrence }\end{array}$ \\
\hline & $\begin{array}{l}\text { Case } 2 \\
\text { Right orbit, } \\
\text { ethmoid and } \\
\text { maxillary } \\
\text { sinuses, } \\
\text { cavernous } \\
\text { sinus }\end{array}$ & $4 / F$ & Angiomyxoma & $\begin{array}{l}\text { Proptosis, ptosis, } \\
\text { afferent pupillary } \\
\text { defect, decreased } \\
\text { visual acuity }\end{array}$ & $\begin{array}{l}\text { CT revealed a right } \\
\text { posterior, subperiosteal, } \\
\text { superomedial, } \\
\text { homogenous mass with } \\
\text { erosion of the medial } \\
\text { orbital wall as well as } \\
\text { a right maxillary sinus } \\
\text { retention cyst. Magnetic } \\
\text { resonance imaging } \\
\text { showed a 30x } 21 \times 15- \\
\text { mm mass extending } \\
\text { to the orbital apex and } \\
\text { displacing the optic } \\
\text { nerve. The tumor was } \\
\text { isodense on T1- and } \\
\text { bright on T2- weighted } \\
\text { images; it enhanced with } \\
\text { contrast. }\end{array}$ & $\begin{array}{l}\text { Frontal craniotomy, } \\
\text { orbitotomy, ethmoid } \\
\text { and maxillary sinuses } \\
\text { for removal of tumor, } \\
\text { oral corticosteroids, } \\
\text { orbital exenteration }\end{array}$ & $\begin{array}{l}\text { Vimentin +++ CD34 } \\
+++ \text { factor XIIIA+ } \\
\text { SMA +/- CD68 + } \\
\text { S-100 -, Desmin -, } \\
\text { EMA -, GFAP - }\end{array}$ & $\begin{array}{l}8 \text { years } \\
3 \\
\text { recurrences }\end{array}$ \\
\hline
\end{tabular}




\begin{tabular}{|c|c|c|c|c|c|c|c|c|}
\hline $\begin{array}{l}\text { Authorl } \\
\text { year }\end{array}$ & Location & $\begin{array}{l}\text { Patient } \\
\text { Any } \\
\text { como- } \\
\text { rbidities }\end{array}$ & $\begin{array}{l}\text { Final } \\
\text { diagnosis }\end{array}$ & Clinical features & Imaging & Treatment & IHC & $\begin{array}{l}\text { Follow up, } \\
\text { recurrence }\end{array}$ \\
\hline $\begin{array}{l}\text { Hidayat } \\
\text { et al. } \\
2007^{7}\end{array}$ & $\frac{\text { Case } 3}{\text { Right orbit }}$ & $48 / \mathrm{M}$ & Angiomyxoma & Palpable mass & Not Available & Simple local excision & $\begin{array}{l}\text { Vimentin ++ } \\
\text { CD34 ++ } \\
\text { Factor XIIIA+ } \\
\text { SMA - } \\
\text { Desmin - }\end{array}$ & $\begin{array}{l}15 \text { months } \\
\text { No } \\
\text { recurrence }\end{array}$ \\
\hline \multirow[t]{4}{*}{$\begin{array}{l}\text { Bajaj et } \\
\text { al. } \\
2011^{5}\end{array}$} & $\begin{array}{l}\text { Case } 1 \\
\text { Left } \\
\text { superomedial } \\
\text { orbit }\end{array}$ & $40 / F$ & Angiomyxoma & $\begin{array}{l}\text { Painless palpable } \\
\text { mass, } 6 / 36 \text { visual } \\
\text { acuity }\end{array}$ & $\begin{array}{l}\text { USG suggestive of } \\
\text { heterogeneous mass } \\
\text { with low to medium } \\
\text { amplitude spikes }\end{array}$ & $\begin{array}{l}\text { Complete surgical } \\
\text { removal by anterior } \\
\text { orbitotomy }\end{array}$ & $\begin{array}{l}\text { Diffusereactivity for } \\
\text { vimentin and focal } \\
\text { positivity for CD34. } \\
\text { S-100 - Cytokeratin } \\
\text { - Desmin - }\end{array}$ & $\begin{array}{l}8 \text { years } \\
\text { No } \\
\text { recurrence }\end{array}$ \\
\hline & $\begin{array}{l}\text { Case 2 } \\
\text { Right } \\
\text { superomedial } \\
\text { orbit }\end{array}$ & $32 / \mathrm{M}$ & Angiomyxoma & $\begin{array}{l}\text { Proptosis, } \\
\text { occasional pain, } 6 / 6 \\
\text { both eyes }\end{array}$ & $\begin{array}{l}\text { CT scan: heterogenous } \\
\text { enhancing mass, with } \\
\text { irregular borders, } \\
\text { infiltrating surrounding } \\
\text { tissue and LPS, SR } \\
\text { muscles MRI: tumor } \\
\text { iso intense on T1- and } \\
\text { bright on T2-weighted } \\
\text { images; enhanced with } \\
\text { contrast }\end{array}$ & $\begin{array}{l}\text { Debulking surgery, } \\
\text { recurrence at } 6 \\
\text { months, large solid } \\
\text { mass removed } \\
\text { via superomedial } \\
\text { orbitotomy }\end{array}$ & $\begin{array}{l}\text { Diffuse reactivity for } \\
\text { vimentin and focal } \\
\text { positivity for CD34. } \\
\text { S-100 - Cytokeratin } \\
\text { - Desmin - }\end{array}$ & $\begin{array}{l}1 \text { year } \\
\text { Recurrence } \\
\text { at } 6 \text { months }\end{array}$ \\
\hline & $\begin{array}{l}\text { Case } 3 \\
\text { Right } \\
\text { superomedial } \\
\text { orbit }\end{array}$ & $28 / \mathrm{M}$ & $\begin{array}{l}\text { Aggressive } \\
\text { angiomyxoma }\end{array}$ & $\begin{array}{l}\text { Proptosis, } \\
\text { occasional pain, } 6 / 6 \\
\text { both eyes }\end{array}$ & $\begin{array}{l}\text { CT scan } \\
\text { heterogeneous } \\
\text { enhancing mass, } \\
\text { with irregular borders } \\
\text { infiltrating MR, LPS, SR } \\
\text { muscles }\end{array}$ & $\begin{array}{l}\text { Piecemeal removal via } \\
\text { anterior orbitotomy }\end{array}$ & $\begin{array}{l}\text { Diffuse reactivity for } \\
\text { vimentin and focal } \\
\text { positivity for CD34. } \\
\text { S-100 - Cytokeratin } \\
\text { - Desmin -. }\end{array}$ & $\begin{array}{l}4 \text { years } \\
\text { No } \\
\text { recurrence }\end{array}$ \\
\hline & $\begin{array}{l}\text { Case } 4 \\
\text { Left superior } \\
\text { orbit }\end{array}$ & $40 / \mathrm{M}$ & $\begin{array}{l}\text { Aggressive } \\
\text { angiomyxoma }\end{array}$ & $\begin{array}{l}\text { Proptosis, painless } \\
\text { palpable mass, } \\
\text { decreased visual } \\
\text { acuity of } 6 / 24, \text { RAPD } \\
\text { present }\end{array}$ & $\begin{array}{l}\text { CT scan heterogeneous } \\
\text { enhancing mass, with } \\
\text { irregular borders }\end{array}$ & $\begin{array}{l}\text { Mass removal } \\
\text { via antero-lateral } \\
\text { orbitotomy }\end{array}$ & $\begin{array}{l}\text { Diffuse reactivity for } \\
\text { vimentin and focal } \\
\text { positivity for CD34 } \\
\text { S-100 - Cytokeratin } \\
\text { - Desmin - }\end{array}$ & $\begin{array}{l}20 \text { months } \\
\text { No } \\
\text { recurrence }\end{array}$ \\
\hline $\begin{array}{l}\text { Mishulin } \\
\text { et al. } \\
2012^{9}\end{array}$ & $\begin{array}{l}\text { Right glabella } \\
\text { and infra- } \\
\text { medial brow }\end{array}$ & $62 / \mathrm{M}$ & $\begin{array}{l}\text { Aggressive } \\
\text { Glabellar } \\
\text { Angiomyxoma } \\
\text { with Orbital } \\
\text { Extension }\end{array}$ & Painless mass & $\begin{array}{l}\text { CT Scan: } \\
\text { a } 2.5 \times 1.8 \mathrm{~cm} \text { glabellar } \\
\text { cystic mass with } \\
\text { extension to the right } \\
\text { extraconal anterior orbit. } \\
\text { The underlying cortical } \\
\text { bone was intact, lacking } \\
\text { erosion or invasion. }\end{array}$ & $\begin{array}{l}\text { Mass excision via } \\
\text { glabellar incision }\end{array}$ & NA & NA \\
\hline $\begin{array}{l}\text { Jakobiec } \\
\text { et al. } \\
2015^{1}\end{array}$ & $\begin{array}{l}\text { Left medial } \\
\text { orbit }\end{array}$ & $47 / F$ & \begin{tabular}{|l|} 
Aggressive \\
orbital \\
angiomyxoma \\
with malignant \\
rhabdoid \\
transformation
\end{tabular} & $\begin{array}{l}\text { 1981: painless left } \\
\text { upper and lower } \\
\text { eyelid swelling } \\
\text { 2000: VA 20/20 OD, } \\
\text { 20/30 PS, } 6 \text { mm of } \\
\text { left-sided proptosis, } \\
\text { diplopia on right } \\
\text { gaze, and a palpable } \\
\text { mass below the left } \\
\text { medial canthus } \\
\text { 2012: vision no light } \\
\text { perception in left } \\
\text { eye, frozen globe, } \\
\text { proptosis >35mm, } \\
\text { Severe } \\
\text { lagophthalmos with } \\
\text { bullous interpalpebral } \\
\text { chemosis }\end{array}$ & $\begin{array}{l}\text { CT scan 2000: a } \\
\text { multiloculated mass } \\
\text { with internal septa in } \\
\text { the left medial orbit. The } \\
\text { medial wall of the orbit } \\
\text { was bowed toward the } \\
\text { ethmoid sinus. } \\
\text { CT scan 2012: massive } \\
\text { retro-orbital and medial } \\
\text { orbital mass extending } \\
\text { outwards through the } \\
\text { medial orbital wall } \\
\text { where a previous } \\
\text { decompression with } \\
\text { bone removal had } \\
\text { facilitated spread of } \\
\text { lesional tissue into the } \\
\text { ethmoid sinus }\end{array}$ & $\begin{array}{l}\text { Serial debulking, } \\
\text { medial wall bony orbital } \\
\text { decompression and } \\
\text { dacryocystorhinostomy } \\
\text { Exenteration with } \\
\text { prosthetic } \\
\text { reconstruction } \\
2 \text { courses } \\
\text { chemotherapy for } \\
\text { lung metastasis, } \\
\text { stopped due to non- } \\
\text { responsiveness of the } \\
\text { metastases, patient } \\
\text { intolerance, and poor } \\
\text { prognosis }\end{array}$ & $\begin{array}{l}\text { Vimentin+ } \\
\text { SMA + } \\
\text { Factor XIIla + } \\
\text { Calponin + } \\
\text { Desmin - } \\
\text { CD34 - } \\
\\
\text { For rhabdoid } \\
\text { transformation: } \\
\text { SMA + } \\
\text { EMA + } \\
\text { Calponin + } \\
\text { Myogenin, myosin, } \\
\text { myoglobin, muscle } \\
\text { specific Actin, and } \\
\text { Desmin were negative. } \\
\text { INI1, GFAP, and S100 } \\
\text { were also negative. }\end{array}$ & $\begin{array}{l}>30 \text { years } \\
\text { seven } \\
\text { recurrences }\end{array}$ \\
\hline
\end{tabular}




\begin{tabular}{|c|c|c|c|c|c|c|c|c|}
\hline $\begin{array}{l}\text { Authorl } \\
\text { year }\end{array}$ & Location & $\begin{array}{l}\text { Patient } \\
\text { Any } \\
\text { como- } \\
\text { rbidities }\end{array}$ & $\begin{array}{l}\text { Final } \\
\text { diagnosis }\end{array}$ & Clinical features & Imaging & Treatment & IHC & $\begin{array}{l}\text { Follow up, } \\
\text { recurrence }\end{array}$ \\
\hline $\begin{array}{l}\text { Pujari } \\
\text { et al } \\
2018^{10}\end{array}$ & $\begin{array}{l}\text { Left } \\
\text { conjunctiva }\end{array}$ & $48 / M$ & $\begin{array}{l}\text { Conjunctival } \\
\text { angiomyxoma }\end{array}$ & $\begin{array}{l}\text { Painless fleshy } \\
\text { conjunctival mass }\end{array}$ & $\begin{array}{l}\text { B-scan } \\
\text { ultrasonography: a } \\
\text { well-defined mass } \\
\text { without any intraocular } \\
\text { extension. } \\
\text { Contrast-enhanced } \\
\text { computed tomography } \\
\text { of the orbit revealed } \\
\text { a well-defined, } \\
\text { heterogeneously } \\
\text { enhancing, mass } \\
\text { lesion confined to } \\
\text { the epibulbar surface } \\
\text { without post-septal } \\
\text { extension }\end{array}$ & $\begin{array}{l}\text { Complete surgical } \\
\text { excision with } 2 \mathrm{~mm} \\
\text { margin on inferior, } \\
\text { nasal, and temporal } \\
\text { side and upto superior } \\
\text { fornix followed by } \\
\text { amniotic membrane } \\
\text { grafting }\end{array}$ & NA & $\begin{array}{l}14 \text { months } \\
\text { No } \\
\text { recurrence }\end{array}$ \\
\hline
\end{tabular}

SMA-Smooth Muscle Actin; EMA-Epithelial membrane antigen; GFAP-Glial fibrillary acidic protein; S-100-S-100 protein; CD-Cluster of Differentiation; INI1- Integrase Interactor 1
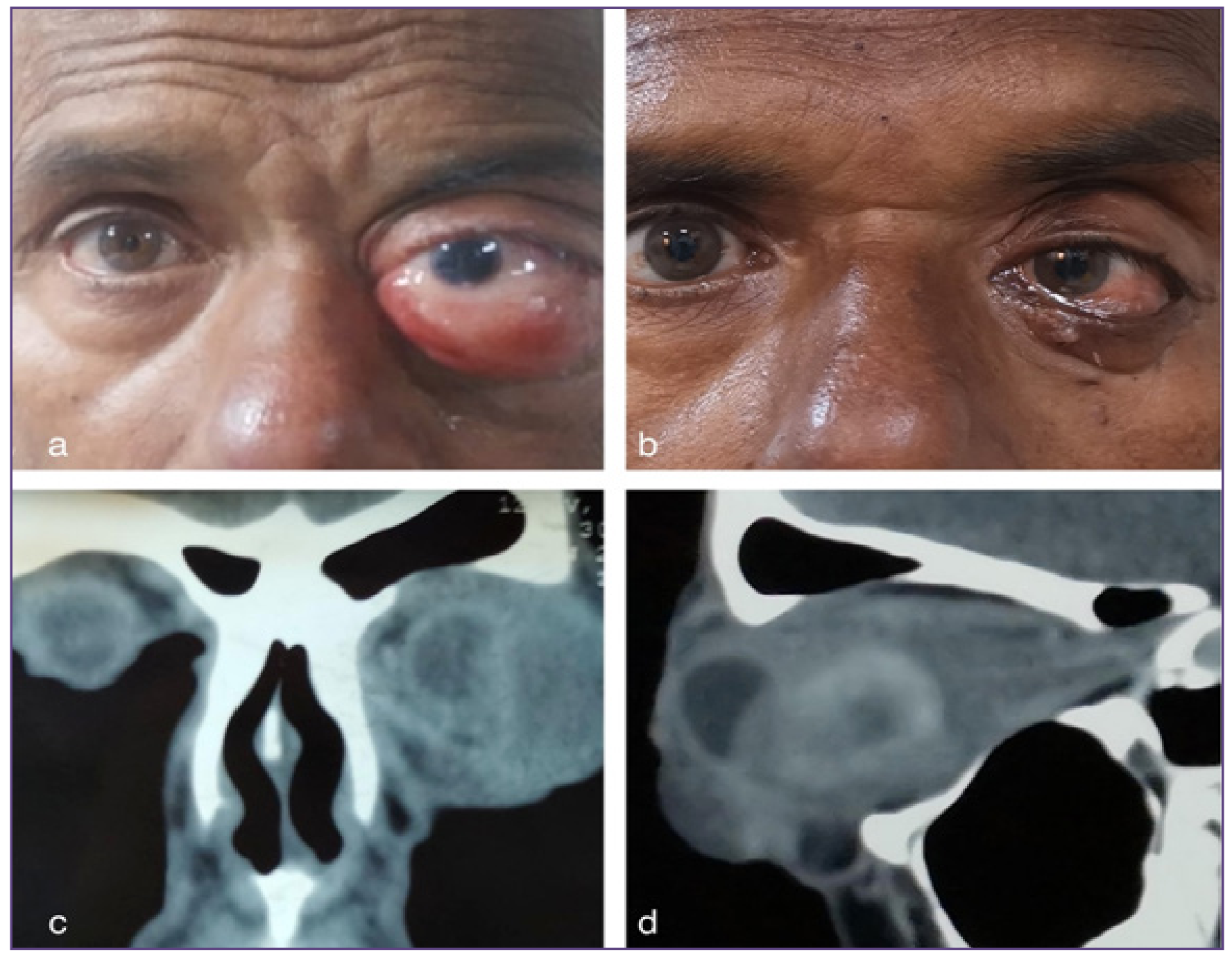

Fig. 1: a) Clinical photograph of the patient at presentation. b) Clinical picture at 6 months postoperative follow up, c, d) Coronal and sagittal sections of CT scan Orbit, showing a heterogeneous lesion in the inferotemporal orbit indenting the left eyeball. 


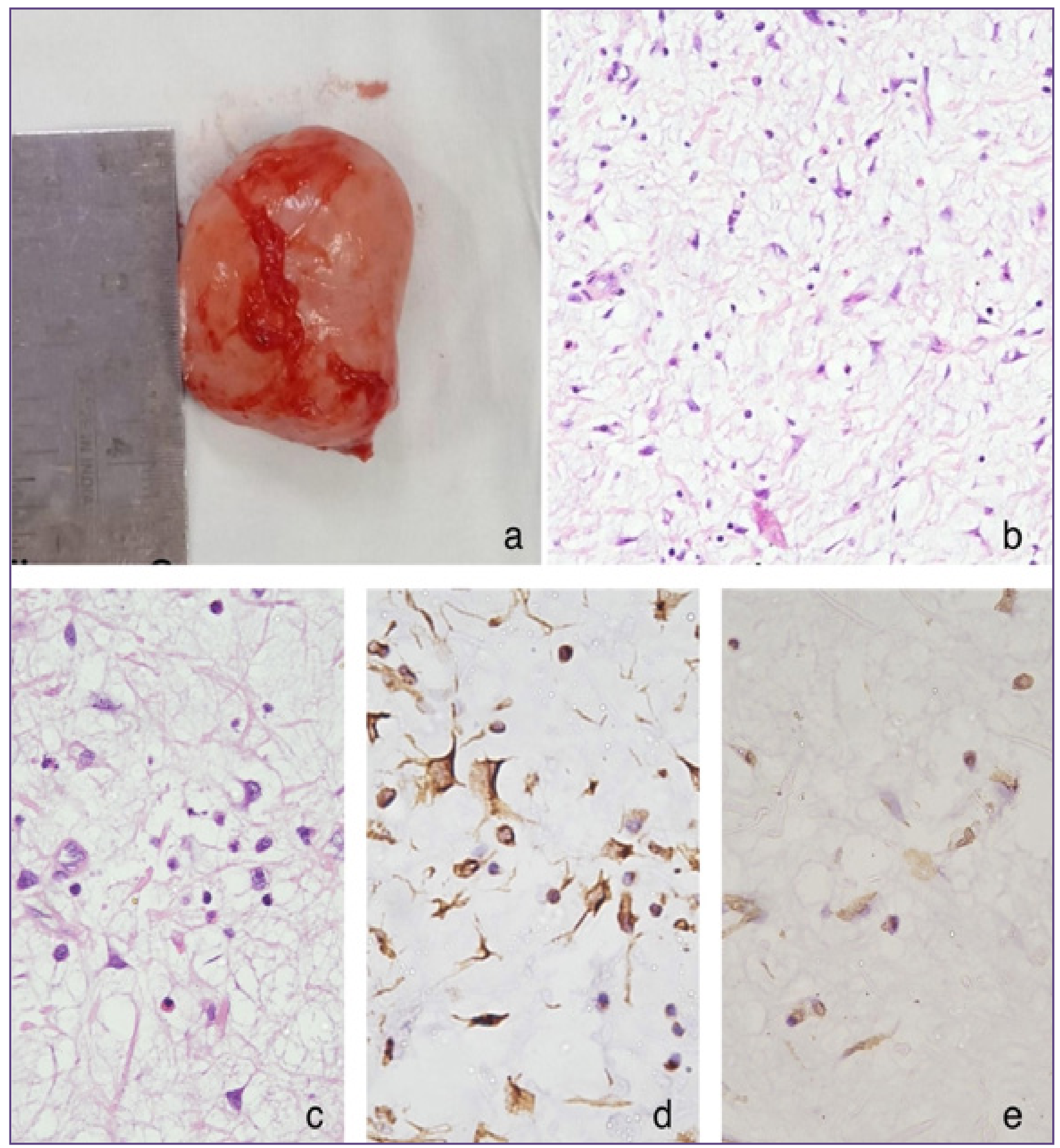

Fig. 2: a) Gross appearance of the lesion.b) Low power view to show tumour cells in a vascularized myxoid stroma. (H\&E $\mathrm{x} 200$ )c) High Power view shows bland spindle and stellate shaped cells. Inflammatory cells are also seen. (H\&E $\mathrm{x} 400$ )d) Cytoplasmic Vimentin (Avidin Biotin x400) e) SMA positivity. (Avidin Biotin x400). 
component to $63 \%$ in tumours with epithelial component [3]. Sites of predilection for superficial varieties involve the trunk but can also appear on the lower limbs, head and neck and pelvic region ${ }^{[4]}$.

Patients are generally middle-aged adults, though cases have been described in young children, usually presenting with a painless gradually progressive mass which may cause proptosis, diplopia, or diminution of vision ${ }^{[5]}$.

Superficial angiomyxoma may form the earliest presenting symptom in cases of Carney's complex, especially associated with external ears. Carney's complex is an autosomal dominant disorder comprising myxomas of the heart and skin, hyperpigmentation of the skin (lentiginosis), and endocrine overactivity ${ }^{[6]}$.

Imaging by computed tomography or magnetic resonance imaging is indicated which reveals a heterogeneously enhancing locally aggressive mass with ill-defined margins and infiltrating surrounding tissues without any bony erosions or intracranial extensions. However, Hidayat et al. described angiomyxomas in two children which manifested locally aggressive behaviour with respiratory sinus, cavernous sinus, and middle cranial fossa bone invasion ${ }^{[7]}$. This may underscore the fact that these tumours may have a more aggressive course in children although distant metastasis has not been reported on long follow-ups.

On gross examination, these tumours are irregular spongy soft tumours which may contain mucoid material and are well vascularized. The jelly-like consistency precludes complete surgical excision. On microscopic examination, these are low-cellularity tumours with bland stellate or spindle-shaped cells in a loosely arranged myxoid matrix that stains avidly with Alcian blue. Abundant vascularity is a distinguishing feature from myxomas. One unique feature, in contrast to other superficial myxoid lesions such as digital myxoma or nerve sheath myxoma, is the presence of neutrophils in the stroma associated with necrosis or ulcer ${ }^{[8]}$. Thin-walled vessels are characteristic of superficial angiomyxoma, whereas large-calibre vessels with thicker walls are more classically found in the deep aggressive variety. Excessive release of hyaluronic acid from fibroblasts allows for infiltrative growth and proptosis within tissues ${ }^{[9]}$. Some of these tumours have an epithelial component associated with a higher rate of recurrence in one study.

Immunohistochemical data pertaining to orbital angiomyxomas is rather limited. In most cases, these tumours have shown positivity for Vimentin, Calponin, CD34 and Factor XIIIa. Negativity for SMA, S-100 and Desmin has also been widely established ${ }^{[7]}$.
Once a diagnosis is established, and any bony or intracranial extension ruled out by imaging, complete surgical excision is the treatment of choice. In many cases where this is not possible, surgical debulking with a margin of safe tissue should be undertaken. Chemotherapy and radiotherapy have limited roles.

Distant metastasis has not been reported even on prolonged periods of follow up. However, an isolated case of malignant rhabdoid transformation with lung and other metastasis in a longstanding case of aggressive angiomyxoma has been reported which is labelled as a composite tumour, thus necessitating early and extensive removal of the tumour ${ }^{[1]}$.

To conclude, angiomyxoma is an extremely rare, locally aggressive orbital tumor, occurring in the fourth to fifth decade of life. The management of orbital angiomyxomas can be quite challenging. A complete excision with margin of healthy tissue has been recommended, but it is difficult due to adhesions and the infiltrative nature of the tumor and therefore tend to recur, requiring long-term follow-up.

\section{Compliance with Ethical Standards}

This report complies with ethical standards and permission from the patient has been taken for publication

\section{Acknowledgement and Disclosure}

Nil

\section{Sources of funding}

None

\section{Conflicts of interest}

None

\section{Written Informed Consent}

The authors affirm that human research participant has provided written informed consent regarding publishing his data and photographs.

\section{References}

1. Steeper, T. A., \& Rosai, J. Aggressive angiomyxoma of the female pelvis and perineum. The American Journal of Surgical Pathology, 1983;7(5), 463-476.

2. Jakobiec, F. A., Callahan, A. B., Stagner, A. M., et al. Malignant rhabdoid transformation of a longstanding, aggressive, and recurrent orbital angiomyxoma. Survey of Ophthalmology 2015;60(2):166-176.

3. Allen, P. W., Dymock, R. B., \& MacCormac, L. B. Superficial Angiomyxomas with and without Epithelial Components. The American Journal of Surgical Pathology, 1988;12(7), 519-530

4. Rodríguez-Vásquez $\mathrm{M}, \quad$ García-Arpa $\mathrm{M}$, Delgado $\mathrm{M}$, et al. Angiomixoma superficial. Actas Dermosifiliogr. 2005;96(5):311-4. 
5. Bajaj MS, Mehta M, Kashyap S, et al. Clinical and pathologic profile of angiomyxomas of the orbit. Ophthal Plast Reconstr Surg. 2011;27:76e80.

6. Kennedy RH, Waller RR, Carney JA. Ocular pigmented spots and eyelid myxomas. Am J Ophthalmol 1987;104:533-538.

7. Hidayat AA, Flint A, Marentette L, et al. Myxomas and angiomyxomas of the orbit: a clinicopathologic study of 6 cases. Ophthalmology. 2007;114:1012e9.
8. Yuen H. K. L, Cheuk, W. Luk, F. O. J., et al. Solitary Superficial Angiomyxoma in the Eyelid. American Journal of Ophthalmology, 2005;139(6), 1141-1142.

9. Mishulin, A., Lever, J. F., Porter, et al. Aggressive Glabellar Angiomyxoma with Orbital Extension. Orbit, 2012;31(5):361-36.

10. Pujari A, Bajaj MS, Sen S, Conjunctival angiomyxomarare but needs observation. Can J Ophthalmol 2018;53:60-62.

*Corresponding author:

Dr. Deepsekhar Das, Oculoplasty and Orbital Tumor Services, Dr. Rajendra Prasad Centre for Ophthalmic Sciences, All India Institute of Medical Sciences, New Delhi-110 029, India

Phone: +918375047749

Email: doc.deep.das@gmail.com

Date of Submission : 03/12/2020

Date of Final Revision : 14/04/2021

Financial or other Competing Interests: None.

Date of Acceptance : 09/04/2021

Date of Publication : 30/04/2021

Annals of Pathology and Laboratory Medicine, Vol. 8, Issue 4, April, 2021 